\title{
Tradução, assimilação, resistência e discurso
}

\section{Translation, assimilation, resistance and discourse}

\section{Giovana Cordeiro Campos de Mello*}

Resumo: Considerando a tradução como uma prática ideológico-discursiva, este artigo propõe uma reflexão sobre o modo como o sujeito-tradutor responde a seu assujeitamento ideológico, aqui tomado como um ritual que admite o equívoco. A partir da Análise do Discurso francesa de Michel Pêcheux, propomos uma reelaboração de dois conceitos dos Estudos da Tradução: assimilação, neste artigo tomado como a repetição de discursos já sedimentados (identificação); e resistência, tomado como os processos de instauração e fortalecimento de discursos dissidentes (contraidentificação e desidentificação).

Palavras-chave: Estudos da Tradução; AD francesa; assimilação; resistência

Abstract: Based on the assumption that translation is a discursive and ideological practice, this paper proposes a reflection on the way that the translator-subject responds to ideological constitution as such subject, in a process considered as a ritual that admits equivocalness. Relying on Michel Pêcheux's French Discourse Analysis, we propose a re-elaboration of two concepts of Translation Studies: assimilation, which in this paper is regarded as the repetition of well established discourses (identification); and resistance, regarded as the processes of settling and strengthening dissident discourses (counter-identification and disidentification).

Keywords: Translation Studies; French DA; assimilation; resistance

\footnotetext{
Universidade Federal Fluminense - UFF; Professora Adjunta de Tradução no GLE/UFF e Coordenadora do Labestrad/UFF; giovanacordeirocampos@gmail.com
} 


\section{Introdução}

Este trabalho apresenta parte das discussões elaboradas na tese de doutorado Assimilação e Resistência sob uma Perspectiva Discursiva: o caso de Monteiro Lobato (2010), cujo objetivo principal é o de aprofundar a relação entre língua e ideologia sem deixar de fora uma discussão a respeito da subjetividade do sujeito-tradutor.

A partir de reflexões dos Estudos da Tradução (como a proposta da singularidade, de Frota, 2000, e a teorização de Lawrence Venuti, 1995, 2002[1998]), e tomando como base as formulações da Análise do Discurso francesa proposta por Michel Pêucheux (AD) e desenvolvida por estudiosos brasileiros, a pesquisa foca os movimentos do sujeito-tradutor na/pela língua tomada como materialidade da ideologia e do inconsciente. Na tese, apresentamos uma releitura do trabalho de Venuti, o qual, a partir de Scheleiermacher (1813), concebe a resistência como a estratégia da estrangeirização. Propomos uma reelaboração desse conceito sob uma perspectiva discursiva, apresentando os movimentos do sujeito-tradutor na e pela língua em duas direções: a da assimilação - a repetição de discursos instituídos - e a da resistência - a da subversão desses discursos.

Neste artigo, iremos nos concentrar no quadro teórico da $A D$ e na proposta de reelaboração dos conceitos de assimilação e resistência a partir desse arcabouço teórico.

\section{A Análise do Discurso Francesa de Michel Pêcheux - AD}

O quadro epistemológico da AD de Michel Pêcheux articula-se no espaço entre o materialismo histórico, observando as formações sociais e suas 
MELLO, G. C. C. DE - Tradução, assimilação, resistência e discurso

transformações; a linguística, considerando os processos de enunciação, porém, com a reelaboração dos conceitos aí envolvidos; e a teoria do discurso, reconhecendo a determinação histórica dos processos semânticos.

Para a AD, não existe uma atividade estanque de codificação e decodificação; trata-se de um ritual de significação no qual há uma relação de sujeitos afetados pela história e pela língua e, nessa relação, os sentidos e os próprios sujeitos se constituem. $O$ sujeito da $A D$ é constituído pela e na relação língua-história-ideologia - há imbricação (e não separação). 0 pressuposto fundamental da $A D$ é que o discurso é "efeito de sentidos" entre interlocutores, e não uma transmissão de informações. Desse modo, a $A D$ entende a significação como um processo semântico dinâmico.

É por meio da interpelação ideológica que Pêcheux esboça sua teoria não subjetivista da subjetividade. Para tal, Pêcheux se remete a outro filósofo, Althusser ([1970] 1985), o qual propõe as ideologias "como conjunto de práticas materiais necessárias à reprodução das relações de produção". Para Althusser, "a questão da ideologia é a questão dos mecanismos ideológicos", cujo efeito é o "reconhecimento da necessidade da divisão do trabalho e do caráter natural do lugar determinado para cada ator social" (pp. 8). A ideologia não estaria no plano das ideias; ela tem um caráter material, em um aparelho ideológico do Estado (jurídico, político, religioso etc.).

Althusser sustenta que a ideologia interpela indivíduos concretos em sujeitos:

Sugerimos, então, que a ideologia "age" ou "funciona" de tal forma que ela "recruta" sujeitos dentre os indivíduos (ela os recruta a todos), ou "transforma" os indivíduos em sujeitos (ela os transforma a todos) através dessa operação muito precisa que chamamos interpelação, que pode ser entendida como o tipo mais banal de interpelação policial (ou não) cotidiana: “ei, você aí” ([1970]1985: 96). 
MELLO, G. C. C. DE - Tradução, assimilação, resistência e discurso

O sujeito é, então, assujeitado à ideologia, sendo que a sujeição existe no plano material de existência: no conjunto de práticas e costumes, localizados em instituições concretas, os quais possuem uma unidade por meio do funcionamento de uma ideologia dominante.

Segundo Pêcheux, o processo de interpelação é ignorado pelo sujeito, constituindo um processo de "imposição/dissimulação", uma vez que o situa - fornecendo ao sujeito o que ele é - ao mesmo tempo em que disfarça o ritual ideológico e discursivo do assujeitamento - dando ao sujeito a ilusão de que ele é origem de seu dizer e de que tem controle sobre o que diz. São desconstruídas, portanto, a concepção de um sujeito que tudo sabe bem como a de um sujeito que escolhe o que diz, sendo a intencionalidade considerada um efeito ideológico-discursivo, que também envolve o inconsciente, espaço da singularidade.

De acordo com Pêcheux, um discurso acontece a partir de condições de produção dadas (CP), as quais são entendidas, em sentido estrito, como as circunstâncias de enunciação, e, em sentido mais amplo, como o espaço sócio-histórico e ideológico. O último remete ao conceito de "memória discursiva", que, por sua vez, relaciona-se à noção de "interdiscurso", um saber discursivo que possibilita às palavras fazerem sentido. 0 interdiscurso é o elemento que faz com que o discurso remeta ao já-dito - os dizeres que, ainda que "esquecidos" pelo sujeito, fazem-se presentes no seu dizer:

Sob a evidência de que "eu realmente sou eu" (com meu nome, [...] minhas "ideias", minhas intenções [...]), há o processo da interpelação-identificação que produz o sujeito no lugar deixado vazio: "aquele que..." [...] Desse modo, é a ideologia que, através do "hábito" e do "uso", está designando, ao mesmo tempo, o que é e o que dever ser [...] É a ideologia que fornece as evidências pelas quais "todo mundo sabe" o que [...], um operário, um patrão [...] evidências que fazem com que uma palavra ou um enunciado "queiram dizer o que realmente dizem" e que mascaram, assim, sob a "transparência da linguagem", aquilo que chamaremos de $o$ caráter material do sentido das palavras e do enunciado (PÊCHEUX [1975]1988:159). 
MELLO, G. C. C. DE - Tradução, assimilação, resistência e discurso

Para a AD não existe um sentido já lá, ou melhor, a transparência do sentido é um efeito ideológico, assim, os sentidos variam de acordo com as diferentes ideologias em questão. O sentido é "determinado pelas posições ideológicas que estão em jogo no processo sócio-histórico no qual as palavras, expressões e proposições são produzidas (isto é, reproduzidas)" (PÊCHEUX [1975]1988: 160). Pêcheux usa "reproduzidas" para salientar o processo de repetição dos dizeres, uma vez que se sustentam no já-dito do interdiscurso. Às diferentes posições ideológicas, Pêcheux denomina "formações ideológicas" - Fls. O sujeito, portanto, não é a origem de seu dizer; é pelo funcionamento da ideologia que ele sabe o que é um operário, um patrão etc. A suposta transparência da linguagem mascara o fato de que os sentidos das palavras não existem "em si mesmos", isto é, "as palavras, expressões, proposições etc., mudam de sentido segundo as posições sustentadas por aqueles que as empregam, o que quer dizer que elas adquirem seu sentido em referência a essas posições", ou seja, em referência às Fls (ibidem: 160). 0 sentido de uma palavra ou expressão, então, pode passar por variações de acordo com as Fls nas quais o enunciador está inscrito:

(...) toda descrição (...) está intrinsecamente exposta ao equívoco da língua: todo enunciado é intrinsecamente suscetível de tornar-se outro (...). Todo enunciado, toda sequência de enunciados é, pois, linguisticamente descritível como uma série (...) de pontos de deriva possíveis, oferecendo lugar a interpretação (PÊCHEUX [1983] 2006: 53).

Por essa perspectiva, Pêcheux recorre ao termo "formação discursiva" (FD), proposto por Foucault (1969), e o redimensiona, chamando de FD "aquilo que, numa formação ideológica dada, isto é, a partir de uma posição dada numa conjuntura dada, determinada pelo estado da luta de classes, determina o que pode e deve ser dito" (PÊCHEUX [1975] 1988: 160). Os discursos são modelados por Fls, podendo a FD ser entendida como a forma pela qual uma $\mathrm{Fl}$ ou mais se manifesta(m) em um dado processo de enunciação. Os indivíduos são interpelados em sujeitos pelas FDs que 
MELLO, G. C. C. DE - Tradução, assimilação, resistência e discurso

“representam 'na linguagem' as formações ideológicas que thes são correspondentes" (ibidem: 161). Para Pêcheux, a FD é "o lugar de constituição do sentido", ou seja, sua "matriz" (ibidem: 162). Todavia, as FDs não devem ser pensadas aqui como um bloco homogêneo: são "regionalizações do interdiscurso, configurações específicas dos discursos em suas relações" (ORLANDI [1999] 2005: 43). É por meio do conceito de FD que entendemos a mobilidade de sentidos, e os processos de assimilação e resistência do sujeito, incluído o sujeito-tradutor, nossa proposta.

$\mathrm{Na}$ passagem de uma FD à outra, as supostas "mesmas" palavras e expressões podem adquirir outros sentidos, de acordo com essa nova matriz. De qualquer modo, seja nesta ou naquela FD, a ilusão de transparência do sentido é sempre mantida pela dissimulação que toda FD realiza no processo ideológico que a produz. Segundo Pêcheux ([1975]1988: 162), "toda formação discursiva dissimula, pela transparência do sentido que nela se constitui, sua dependência com respeito ao 'todo complexo com dominante' das formações discursivas". Logo, o ritual interpelação/assujeitamento é apagado aos olhos do sujeito, que esquece que é assujeitado à ideologia. As Fls formam um conjunto que tem entre si uma $\mathrm{Fl}$ dominante - o "todo complexo com dominante" (PÊCHEUX, [1975]1988: 162), o qual o filósofo propõe chamar de "interdiscurso". 0 interdiscurso é algo que fala "sempre antes, em outro lugar e independentemente". É por meio do interdiscurso que o sujeito concebe a sua "realidade enquanto sistema de evidências e de significações percebidas - aceitas, experimentadas".

Ainda no âmbito das FDs, Pêcheux toma de Althusser o termo "formasujeito", o qual se referia à forma de existência histórica de qualquer indivíduo, apresentando-o como o "sujeito universal" de uma FD, com a qual o sujeito irá se identificar (ou não). O processo de identificação do sujeito com uma formação discursiva fica assim resumido:

Já observamos que o sujeito se constitui pelo "esquecimento" daquilo que o determina. Podemos agora precisar que a interpelação do indivíduo em sujeito de seu discurso se efetua pela 
MELLO, G. C. C. DE - Tradução, assimilação, resistência e discurso

identificação (do sujeito) com a formação discursiva que o domina (isto é, na qual ele é constituído como sujeito): essa identificação, fundadora da unidade (imaginária) do sujeito apoia-se no fato de que os elementos do interdiscurso (...) que constituem, no discurso do sujeito, os traços daquilo que o determina, são reinscritosno discurso próprio do sujeito (PÊCHEUX [1975] 1988: 163).

Ou seja, o sujeito é constituído pela sua sujeição a uma FD que o determina e a seus dizeres. E nesse sentido, o "intradiscurso" - fio do discurso do sujeito - é um efeito do interdiscurso, sendo que a forma-sujeito com a qual o sujeito se identifica caracteriza-se por incorporar, ao mesmo tempo em que dissimula, os elementos do interdiscurso no intradiscurso. É pelo esquecimento que o sujeito tem a ilusão de ser a origem do que diz, sentindo-se responsável pelos dizeres. A autoria do sujeito é, portanto, um efeito da necessária ocultação do processo de identificação do sujeito com o sujeito universal de uma FD. Desse modo, entendemos que o sujeito da AD não é um indivíduo, mas uma posição ideológica a partir da qual se constituem os sentidos. Assim, em AD se fala em várias "posições-sujeito", as quais estão relacionadas às Fls por meio das FDs. Nas palavras de Indursky (1997: 27-28)

(...) o sujeito, ao produzir seu discurso, o faz a partir de determinadas posições de sujeito, igualmente ideológicas. Tais posições, contudo, não transformam esse sujeito em uma figura que decide livremente seu discurso, pois se trata de um sujeito socialmente constituído. No entanto, por não ter consciência de seu assujeitamento, mantém fortemente arraigada a ilusão de ser plenamente responsável por seu discurso e suas posições (...)

O sujeito representa a forma-sujeito a partir de uma posição-sujeito, ou seja, ele é efeito da forma-sujeito e o funcionamento de diferentes FDs vai representar diferentes posições, possíveis porque o discurso é heterogêneo. 0 sujeito da AD é, portanto, uma posição material linguístico-histórica (MARIANI 2003: 61), produzida no jogo das tensões sócio-históricas e políticoideológicas. 
Pêcheux apresenta três modalidades de relação entre o sujeito da enunciação e o sujeito universal da FD (ou, a forma-sujeito da FD), as quais denominou identificação (repetição de discursos instituídos), contraidentificação (relacionado ao "discurso contra") e desidentificação (movimento de ruptura). Esses três movimentos constituem o cerne de nossa proposta: uma relaboração dos conceitos de assimilação e resistência nos estudos da tradução.

A AD também é constituída em sua interface com a Psicanálise. De um modo geral, para ambas, o sujeito não é dado, mas construído, e pensar o sujeito envolve pensar a linguagem. Para Lacan (1998 [1966]), o inconsciente é estruturado como linguagem e o sujeito está no espaço do que um significante representa para outro significante. Quando falamos, o fazemos a partir desse espaço

(...) que inclui o vazio (o espaço entre os significantes) e traz a marca da distância entre a linguagem e o mundo. É por isso que, de acordo com Lacan, o sujeito falante [...] é um sujeito dividido pelo funcionamento da linguagem [...] Quando dizemos "eu" (o "eu" do teatro da consciência), o fazemos submetidos às leis do funcionamento estrutural da linguagem, as leis que nos permitem fazer uso de uma língua e que, simultaneamente, nos colocam frente a esse vazio, a esse hiato, a essa negatividade que habita a linguagem (MAGALHÃES; MARIANI 2010: 394).

A Psicanálise já se apresentava na teoria pecheusiana na proposta dos esquecimentos: o esquecimento número 1 (que para Pêcheux é da ordem do "pré-consciente") refere-se à ilusão de que o sujeito é a origem do dizer e $o$ esquecimento número 2 refere-se à ilusão de que o sujeito tem o domínio sobre o que diz. Aprofundando a relação entre o dizer e as rupturas, Pêcheux, em "Só há causa daquilo que falha ou o inverno político francês: início de uma retificação" ([1978] 1988), reforça sua ligação com Lacan, revendo os processos de identificação e discutindo que os sentidos podem ser outros, não havendo dominação sem resistência (pp. 304): 
MELLO, G. C. C. DE - Tradução, assimilação, resistência e discurso

Só há causa daquilo que falha (J. Lacan). É nesse ponto preciso que ao platonismo falta radicalmente o inconsciente, isto é, a causa que determina o sujeito exatamente onde o efeito de interpelação o captura; o que falta a essa causa, na medida em que ela se "manifesta" incessantemente e sob mil formas (o lapso, o ato falho, etc.) no próprio sujeito, pois os traços inconscientes do significante não são jamais "apagados" ou "esquecidos", mas trabalham, sem se deslocar, na pulsação sentido/non-sens do sujeito dividido (pp. 300).

Para Pêcheux, "levar demasiadamente a sério a ilusão de um ego sujeito-pleno em que nada falha" é o que "falhou" em sua proposta ([1978]1988: 300). A partir de Lacan, Pêcheux busca abrir caminho para a falha, para se compreender "de que modo a ação do significante no sujeito abre caminho para o que fracassa: pois, há causa para o que falha" (LEITE 2005: 80).

Inconsciente e ideologia estão em relação; daí a necessidade de se voltar às formulações sobre as identificações a partir das colocações de Lacan. O fracasso da identificação, a partir da abordagem de uma formasujeito fragmentada, tal como a realizada por Indursky (2000) a partir de Courtine (1981), pode auxiliar na compreensão do entrecruzamento entre linguagem, ideologia e inconsciente. Segundo Ferreira, "o sujeito constituído pela linguagem manifesta-se como efeito de linguagem; ao ser interpelado pela ideologia como sujeito, comparece como assujeitado; e, ao ser atravessado por uma teoria não subjetiva da subjetividade, marca-se como desejante" (2005: 69). Acreditamos no desejo do inconsciente como a raiz tanto de outro assujeitamento, como também da resistência.

\section{Assimilação e Resistência: uma proposta discursiva}


MELLO, G. C. C. DE - Tradução, assimilação, resistência e discurso

O teórico e tradutor Lawrence Venuti vem promovendo uma ampla discussão sobre a tradução, mostrando-a como uma tarefa eminentemente política. Dentre as suas propostas está a estratégia de resistência (resistance strategy), um modo de ação política por parte do tradutor que poderia retirálo de sua condição de invisibilidade e permitir uma troca cultural concreta.

Venuti sustenta que a percepção da tradução como uma atividade que está a serviço de uma ideologia descortina assimetrias, ilumina relações de dominação e dependência ([1998]2002: 5) e, por essas razões, a tradução é "escandalosa". Um escândalo é revelado quando consideramos que a escolha de uma determinada estratégia tradutória pode criar valores e práticas diferentes do modelo cultural vigente no contexto receptor, proporcionando, dessa forma, uma abertura para a alteridade, para a visualização do outro e, portanto, permitindo que se opere uma inscrição de valores estrangeiros no contexto doméstico. A essa estratégia Venuti dá o nome de "tradução estrangeirizadora" (foreignizing translation). Por outro lado, se a tradução está voltada para a produção de um texto fluente, temos a chamada "tradução domesticadora" (domesticating traslation). 0 texto caracterizado pela fluência (fluency) é, segundo Venuti ([1986]1995: 111), aquele texto em que não há "passagens canhestras [...] ou significados confusos [transmitindo] a sensação de que a tradução reflete a personalidade ou a intenção do autor estrangeiro". Em outras palavras, o tradutor privilegia o contexto receptor e, com ele, os valores domésticos padrão, o que acarreta o apagamento de marcas culturais e linguísticas do texto de partida, bem como daquelas que são tidas como "marginais" pelas classes hegemônicas da sociedade de chegada, gerando o efeito de transparência (transparency).

A estratégia estrangeirizadora é a defendida por Venuti e a que se relaciona com a resistência na sua teorização. O termo "resistência" (resistance ou resistancy, em inglês) muitas vezes é tomado como sinônimo para "tradução estrangeirizadora" (foreignizing translation). Ao filiar-se à prática estrangeirizadora, Venuti pretende subverter no universo angloamericano a hegemônica tendência domesticadora da operação tradutória a 
MELLo, G. C. C. DE - Tradução, assimilação, resistência e discurso

se conformar aos moldes político-ideológicos vigentes no contexto-meta, vindo a produzir textos fluentes e "transparentes". Ao lado da sua proposta da estratégia de resistência, o teórico conceitua a "leitura sintomática" (symptomatic reading), termo usado em oposição à "leitura desistoricizante", ou "leitura de assimilação" (assimilative reading). A leitura sintomática, inspirada na arqueologia foucaultiana, seria menos inocente e mais profunda, capaz de fazer o tradutor perceber a tessitura sócio-histórica e políticoideológica do texto-fonte e de possibilitar ao tradutor a manutenção das diferenças existentes entre os contextos de partida e de chegada.

A proposta de Venuti representou um importante passo em direção à compreensão de que os estudos sobre a tradução podem descortinar relações ideológicas e políticas. Contudo, como nos mostra Frota (2000), essa abordagem pressupõe um tradutor capaz de perceber e controlar as contingências político-ideológicas. A partir das formulações da AD, pode ser colocado que há relações sócio-históricas e político-ideológicas que não são conscientemente percebidas bem como há aquelas que, para além disso, são constituídas na/pela história particular do sujeito que traduz, ainda que não haja marcas visíveis.

Apresentamos uma reelaboração dos conceitos de assimilação e de resistência nos Estudos da Tradução via $A D$ francesa, com as modalidades de tomada de posição do sujeito, a saber, a identificação, a qual propomos como assimilação, e as de contraidentificação e desidentificação, as quais propomos serem identificadas como resistência.

Foi Foucault (1969) que, em $A$ arqueologia do saber, propôs o termo formação discursiva. Em sua busca para entender e descrever as relações entre enunciados no campo do discurso, ele percebeu que havia entre essas relações séries lacunares, desvios, jogos de diferenças que o levaram a falar em "sistemas de dispersão" (Foucault, [1969] 2005: 42), a partir dos quais cunhou o termo formação discursiva. Segundo Foucault, a formação discursiva (FD) relaciona um sistema de dispersão onde se percebe certa regularidade. Haveria regras de formação, ou seja, condições de existência, coexistência, 
manutenção, modificação e desaparecimento. A regularidade dos enunciados é definida pela FD, e o conjunto de enunciados que se apoiam em uma FD constituem o discurso. Indursky (2007) observa que essas regularidades propostas por Foucault determinam uma FD homogênea e fechada, uma vez que haveria um sistema vertical de dependências. Cogita-se a transformação, mas somente se submetida à regra principal da regularidade (INDURSKY 2007: 164).

A partir de uma reelaboração do conceito, Pêcheux e Fuchs (1975) propõem as FDs em relação às formações ideológicas (FIs), conjunto complexo de representações e atos que se relacionam com as posições de classe. As Fls comportam uma ou mais FDs, as quais estão interligadas e "determinam o que pode e deve ser dito [...] a partir de uma posição dada numa conjuntura, isto é, numa certa relação de lugares no interior de um aparelho ideológico e inscrita numa relação de classes" (PÊCHEUX; FUCHS [1975]1997: 166-167). Assim, o conceito de FD em AD está diretamente relacionado ao de ideologia, sendo noção central pela qual se articulam ideologia, sujeito e língua. As diferentes Fls se materializam nas diferentes FDs, as quais representam, na ordem do discurso, as Fls que thes são correspondentes (PÊCHEUX [1975]1988: 161).

O sujeito da AD, como apontou Indursky (2000: 71)

(...) além de social é histórico, por conseguinte, ideológico, e dotado de inconsciente [...] a constituição do sujeito da Análise do Discurso articula fortemente o social (a relação com a História) e o inconsciente (a relação com o dizer do outro). Em outras palavras, o sujeito da Análise do Discurso é duplamente afetado: em seu funcionamento psíquico, pelo inconsciente, e em seu funcionamento social, pela ideologia.

Desse modo, a relação do sujeito com a língua passa pela consideração da esfera do inconsciente, possibilitando, além de uma relação com a proposta da singularidade, de Frota (2000), também com os movimentos de tomada de posição do sujeito proposta por Pêcheux (1975). 
MELLO, G. C. C. DE - Tradução, assimilação, resistência e discurso

$\mathrm{Na} A D$, é pela relação entre o sujeito e as FDs que entendemos o funcionamento do sujeito no discurso. 0 sujeito é interpelado por meio de sua identificação com a FD que o domina (na qual ele é constituído como sujeito). Esta identificação acontece via forma-sujeito, ou seja, pela existência histórica do sujeito, o que o filósofo também denomina de "sujeito universal", "Sujeito" ou "o sujeito do saber" de uma FD. Segundo Indursky (2000), a princípio, a forma-sujeito é apresentada por Pêcheux como sendo homogênea, contudo, por meio de uma análise das "modalidades das tomadas de posição" do sujeito, as quais o filósofo denomina de identificação, contraidentificação e a desidentificação, essa homogeneidade é revista, o que nos interessa diretamente para a realização de análises concernentes ao processo tradutório.

Segundo Pêcheux, o sujeito (des)conhece o processo de determinação pelo qual está assujeitado, logo, a tomada de posição do sujeito "não é, de modo algum, concebível como 'ato originário' do sujeito-falante" (PÊCHEUX [1975]1988: 172). Além disso, a tomada de posição do sujeito resulta de um retorno do "Sujeito" no sujeito. Com base nessas considerações, podemos acrescentar que o movimento do sujeito é duplamente determinado: pela ideologia, na figura da interpelação, e pela história particular do sujeito, que se relaciona com o processo de significação de cunho singular; ou seja, é na imbricação entre ideologia e inconsciente que podemos entender melhor os processos de tomada de posição do sujeito nas diferentes modalidades propostas por Pêcheux. Portanto, as "escolhas" do sujeito (o que inclui as escolhas do sujeito-tradutor) não são totalmente percebidas; estão no âmbito do que é consentido (ou proibido) no escopo da FD de onde ele fala, sendo que esse movimento de sobreposição ou não do sujeito com o Sujeito da FD também tem relação com a maneira que o sujeito tomou os sentidos para os eventos particulares de sua existência física.

A modalidade da identificação consiste na sobreposição plena do sujeito com a forma-sujeito da FD que o domina. Essa modalidade produz o que Pêcheux denominou "bom sujeito", no qual a tomada de posição do 
MELLO, G. C. C. DE - Tradução, assimilação, resistência e discurso

sujeito realiza o assujeitamento sob a forma do "livremente consentido". Pela identificação, os elementos do interdiscurso, que constituem no discurso do sujeito os traços daquilo que o determina, são reescritos no discurso do próprio sujeito: "o interdiscurso determina a formação discursiva com a qual o sujeito, em seu discurso, se identifica, sendo que o sujeito sofre cegamente essa determinação, isto é, ele realiza seus efeitos 'em plena liberdade'” (PÊCHEUX [1975] 1988: 215). Este é o movimento que dá conta da manutenção dos valores e dizeres dominantes. Em nosso trabalho, propomos o termo assimilação com referência a essa modalidade, uma vez que o movimento de sobreposição do sujeito com o Sujeito não gera um processo de transformação/inovação, mas repetição, daí a pertinência do termo assimilação.

A contraidentificação, por outro lado, consiste em uma tomada de posição que se contrapõe ao sujeito universal da FD:

A tensão, que ocorre no interior da forma-sujeito, estabelece a diferença em seu interior e, por conseguinte, no âmbito da formação discursiva, daí decorrendo a instauração da diferença e da contradição, não apenas no âmbito da Formação Discursiva, mas também da própria forma-sujeito (INDURSKY 2000: 73).

Essa modalidade representa uma separação (distanciamento, dúvida, revolta) "com respeito ao que o 'sujeito universal' lhe dá a pensar: luta contra a evidência ideológica" (PÊCHEUx [1975]1988: 215), isto é, o sujeito se distancia do saber da FD em questão, gerando desdobramentos. Percebemos um movimento de resistência, uma vez que o sujeito se aproxima do que "não pode" e "não deve ser dito" da FD que o domina, mas a força não é suficiente para alterar a posição-sujeito dominante que marca o "Sujeito". Mesmo assim, ainda que não haja uma total desestabilização do Sujeito da FD em questão, há pelo menos um gesto que instaura/fortalece a dissidência, abrindo caminho para uma possível subversão dos dizeres estabelecidos. Em outras palavras, tem-se reforçada a heterogeneidade da FD pelo fortalecimento do contradiscurso, daí a pertinência do termo resistência para 
MELLO, G. C. C. DE - Tradução, assimilação, resistência e discurso

nomear a segunda modalidade de tomada de posição do sujeito proposta por Pêcheux.

A desidentificação, por sua vez, representa o funcionamento "às avessas" da ideologia, o que também tomamos por resistência. Nessa modalidade, o sujeito se desidentifica com a forma-sujeito da FD a ponto de promover a transformação da forma de organização da FD em questão. Pêcheux ressalta que a ideologia não desaparece; ocorre um "desarranjo/rearranjo" do complexo das Fls com as respectivas FDs: “" sentido não 'morre', o sujeito não 'desaparece'... A repercussão consiste num trabalho na e sobre a forma-sujeito" (PÊCHEUX [1975]1988: 269), de modo que a interpelação ideológica continua a atuar, porém, "contra si mesma" (Ibidem: 271).

Segundo Indursky (2000: 74), as diferentes modalidades de tomada de posição apontam para esse "trabalho na e sobre a forma-sujeito", de modo a fazer da FD espaço também da "instauração da diferença e da desigualdade de saberes". Além disso, no processo de desidentificação, o sujeito vai além da divergência com os saberes de uma FD, "ele rompe com a FD em que se inscreve e, por via de consequência, com a forma-sujeito que organiza os saberes da referida FD" para novamente se identificar com outra FD e seu sujeito universal; ou seja, o sujeito não se torna livre, há um movimento de uma forma de subjetivação para outra.

Indursky salienta que Pêcheux define o interdiscurso como um todo complexo de formações discursivas com dominante. Logo, no complexo das FDs há uma que é dominante, havendo, portanto, uma correspondente formasujeito dominante. Assim, as diferentes modalidades se referem à relação do sujeito com a forma-sujeito dominante e, portanto, a desidentificação conduz à operação de identificação com outra forma-sujeito que não é dominante. Por analogia, Indursky (2000: 74) conclui que

Se há um complexo de formações discursivas ligadas entre si, há igualmente um complexo de formas-sujeito também ligadas entre si 
MELLO, G. C. C. DE - Tradução, assimilação, resistência e discurso

e a desidentificação conduz à identificação com alguma destas outras formas-sujeito, que podemos entender como secundárias.

Segundo Courtine (1982 apud INDURSKY 2000: 75), a FD “não é só um discurso para todos, não é também a cada um seu discurso, mas deve ser pensada como dois (ou mais) discursos em um só”. Assim, a FD passa a ser concebida como heterogênea, sendo essa heterogeneidade uma propriedade também da forma-sujeito; isto é, a forma-sujeito abriga a diferença e ambiguidade em seu interior. O resultado dessa reflexão é que o sujeito da $A D$ é visto como dividido entre as diversas posições de sujeito que sua interpelação ideológica permite. Essas posições de sujeito constituem "modalidades particulares de identificação do sujeito da enunciação ao sujeito do saber, com os efeitos discursivos específicos que the estão ligados" (INDURSKY 2000: 76). A partir de uma forma-sujeito fragmentada chegamos a uma concepção de sujeito que é fragmentado entre as diferentes posições de sua interpelação ideológica:

Num espaço com tais características, o sujeito só pode acompanhar e ser igualmente fragmentado entre as diferentes e divergentes posições que pode assumir em decorrência dos diferentes modos que encontra para identificar-se ou contra-identificar-se com o saber de uma Formação Discursiva, cujas "fronteiras se deslocam" [COURTINE 1981: 49] para acomodar saberes que migram, que vêm de fora, do interdiscurso (INDURSKY 2000: 76).

A partir da fragmentação da forma-sujeito, o sujeito passa a identificar-se com o sujeito universal por meio de diferentes posições-sujeito (os diferentes modos de se relacionar com a forma-sujeito) que podem marcar até mesmo grandes desigualdades.

Para ilustrar, tomemos a análise de Indursky sobre o Movimento dos Trabalhadores Rurais sem-terra, MST. Dentre as várias posições-sujeito da FD dos Sem-Terra, a autora destaca duas: a do MST e a dissidente do MST. Para exemplificar, é apresentada uma sequência discursiva (SD) retirada de uma 
MELLO, G. C. C. DE - Tradução, assimilação, resistência e discurso

entrevista dada por Cícero F. Neto, líder do movimento dissidente Topa-Tudo, à Folha de São Paulo em setembro de 1995

(...) o confronto de Corumbiara virou uma nova referencia do Movimento sem-terra. A luta pela terra não é só do MST... O MST precisa entender que há lutas que o movimento não está abarcando.... O MST não abarca todos os sem-terra... Enquanto tiver uma família sem terra em Rondônia, estaremos na luta. Com ou sem MST, que deveria representar os sem-terra (INDURSKY 2000: 78 , grifos nossos).

A partir das sequências discursivas de referência - SDR (trechos grifados), observamos uma voz que "entra em colisão" com a do MST, em um movimento de contraidentificação com os princípios da instituição. Segundo Indursky (2000:78), "dito de outra maneira, esse afastamento da posiçãosujeito do MST conduz à instauração de outra posição-sujeito. Estamos, pois, diante de duas posições-sujeito: a do MST e a da dissidência do MST".

A partir dessa constatação, a autora discute a necessidade de uma tomada de posição teórica, qual seja a de considerar que a partir da dissidência se formam duas FDs ou optar por uma única FD que comporta em seu interior saberes divergentes. A autora escolhe o caminho da FD heterogênea, considerando a realização da forma-sujeito "no tenso entrelaçamento das diferentes posições de sujeito", advinda de um processo de contraidentificação que abre espaço para saberes outros, diversos, tensos, contraditórios (ibidem: 79). Assim, as diferentes posições de sujeito apontam para as diferentes formas de o sujeito se relacionar com a ideologia. 0 que acontece, porém, é que há uma dominância, no caso acima, da posiçãosujeito do MST. Contudo, cabe ressaltar que foi aberto o espaço da luta que pode, em algum momento, criar uma inversão e transformar a posição-sujeito dissidente em hegemônica. Indursky (2000: 81) salienta que o movimento dissidente apresentado não configura um movimento de desidentificação, uma vez que tal somente ocorreria se fosse criado um novo domínio de saber, sob o qual o processo da interpelação se diferenciasse. Dito de outra maneira, 
MELLO, G. C. C. DE - Tradução, assimilação, resistência e discurso

permanece um denominador comum - a luta pela terra -, o "saber primordial dessa formação discursiva heterogênea", o qual une todos os semterra, embora o modo de lutar seja diverso. O mesmo caminho da heterogeneidade da FD e, consequentemente, da forma-sujeito, foi por nós tomado ao propormos, mais adiante, uma FD da/sobre a tradução no Brasil

Segundo Indursky, o próprio Pêcheux, no trabalho "Remontémonos de Foucault a Spinoza" ([1977]1980) havia revisto sua definição de ideologia propondo que ela não é igual a si mesma: "só existe sob a modalidade da divisão, e não se realiza a não ser na contradição que com ela organiza a unidade e a luta dos contrários", ou seja, a ideologia é heterogênea, existindo "sob o signo da contradição" (PÊCHEUX apud INDURSKY 2000: 75).

Entendemos, portanto, que o conceito de FD (e com ele o de FI) como unidade dividida, tal como foi proposto e reformulado no campo de estudos da $A D$ francesa, constitui espaço para a instauração da diferença. Acreditamos chegar, dessa forma, à compreensão de que o movimento do sujeito-tradutor vai além da proposta venutiana da resistência apenas como estratégia de estrangeirização. A resistência entendida como 0 movimento de contraidentificação - início da forma de luta do sujeito - e de desidentificação - vitória do processo de revolta - passa a ser considerada um movimento bem mais amplo, que envolve ideologia e inconsciente no movimento do sujeito no complexo de formações discursivas, as quais representam formações ideológicas distintas.

\section{Uma sugestão de análise}

Para este artigo, exemplificamos nossa proposta de análise a partir de sequências discursivas referentes ao pensamento de Lobato. Para melhor entendermos os processos ideológicos que constituem a "fala" lobatiana no que respeita à tradução, pensamos quais seriam as FDs mobilizadas na 
MELLO, G. C. C. DE - Tradução, assimilação, resistência e discurso

constituição do sujeito e discurso lobatianos na primeira metade do século XX. Como nosso objetivo é pesquisar as tomadas de posição do sujeito-tradutor, propomos ser a FD discursiva da/sobre a tradução no Brasil a que nos interessa investigar. Chegamos a essa FD a partir do conceito de formação discursiva heterogênea e nossa proposta é considerar uma FD que comporta os dizeres, e com eles, as ideologias que constituem o modo como se fala/faz a tradução no Brasil. A esta FD nomeamos FD da/sobre a tradução no Brasil, a qual, pela heterogeneidade, comporta posições-sujeito dissidentes em seu interior.

Na década de 1930, Lobato escreveu o artigo "Je prends le Soleil" para o jornal La Prensa, de Buenos Aires, que, em novembro de 1938, foi publicado no Jornal Cultura, de São Paulo, sob o título de "Eu tomo o Sol". Nesse artigo, Lobato aborda a tradução que realizou da obra Mme. Curie, de Eva Curie, e tece inúmeros comentários sobre tradução. Esse artigo é relevante por ser um texto no qual Lobato constrói várias metáforas para explicar a complexidade da atividade tradutória.

Há uma tradição nos estudos da tradução do uso de metáforas diversas para descrever a atividade. Cícero, em 46 a.C., já havia usado metáforas para entender/explicar a tradução: aquele que traduz palavra por palavra seria o "intérprete", o verdadeiro tradutor, enquanto aquele que, como ele, praticava a imitação, seria o "orador". Na França dos séculos XVI e XVII, por exemplo, foi usada a metáfora das "belas infiéis". Walter Benjamin, em 1923, escreveu o texto "A tarefa do tradutor" (o qual é considerado seminal no campo dos estudos da tradução) como prefácio às traduções de poemas de Baudelaire e usando como metáforas "a tangente e o círculo", o "manto real" e "os vasos quebrados" para tentar dar conta da complexidade da atividade tradutória. O uso lobatiano das metáforas, portanto, aponta para a sua identificação com a tradição da tradução no Brasil e no mundo ocidental e, dessa forma, como um assujeitamento bem-sucedido do sujeito pela FD da/sobre a tradução no Brasil (e no ocidente). As metáforas usadas por Lobato para abordar a tradução ainda não foram completamente estudadas, sendo 
MELLO, G. C. C. DE - Tradução, assimilação, resistência e discurso

nossa análise uma contribuição para os estudos historiográficos da tradução no Brasil.

Lobato inicia seu artigo abordando as formas de ler. Segundo ele, o tradutor seria o leitor por excelência, uma vez que a ele cabe uma das formas mais profundas de leitura - o tradutor seria, portanto, um "escafandrista":

Há muitas maneiras de ler. Talvez que a mais profunda seja a de quem verte um livro para outra língua. 0 tradutor é um escafandrista. Mergulha na obra como num mar; impregna-se dum pensamento concretizado de um certo modo - o estilo do autor - e lentamente o vai moldando no barro de outro idioma, para que a obra não admita fronteiras; Sem esses abnegados trabalhadores, a literatura ficaria adstrita a pátrias, condenada a limites muito mais estreitos do que os permitidos pela sua potencialidade (LOBATO 1959: 237, grifos nossos).

Observamos um movimento de resistência na própria metáfora do escafandrista. 0 trabalho da tradução não é simples como o senso comum costuma fazer crer, mas sim árduo. 0 escafandrista não mergulha no mar sem treinamento e equipamento adequados. Do mesmo modo, não se pode aventurar na tradução sem um preparo, sem um estudo cuidadoso, sem uma leitura profunda da obra a ser traduzida. Se pela FD da/sobre a tradução no Brasil o trabalho tradutório é comumente tomado como sendo de substituição de palavras, o sujeito se contraidentifica com a posição-sujeito dominante dessa FD ao sustentar a complexidade de tal tarefa. Além disso, se o tradutor não era visível no interdiscurso da FD em questão, Lobato chama a atenção para sua participação ativa na construção do novo texto - ele "molda", com um trabalho próprio, as ideias do autor no "barro" de outro idioma. Porém, ao dizer e, portanto, sustentar de alguma forma a existência de um sentido prévio, o sujeito também se identifica com a posição-sujeito dominante da FD da/sobre a tradução no Brasil que nega a mesma interpretação que ele pretendia defender. Há, portanto, ao mesmo tempo um movimento de identificação-assimilação e contraidentificação-resistência, que é próprio de 
MELLO, G. C. C. DE - Tradução, assimilação, resistência e discurso

períodos em que ocorre uma tentativa de romper com discursos e valores instituídos.

Outra materialidade de um movimento de assimilação e ao mesmo tempo resistência é o uso do adjetivo "abnegados". Lobato costumava criticar as instituições religiosas. Além disso, é possível considerar que o discurso religioso está na gênese da própria constituição do discurso da/sobre a tradução no mundo ocidental. Por exemplo, São Jerônimo, na Idade Média, ao mesmo tempo em que defendia a tradução sentido por sentido para a tradução de textos profanos, repete dizeres de um discurso religioso quando afirma que nas Sagradas Escrituras, "até a ordem das palavras encerra mistério" (apud FURLAN 2003: 14). Segundo Caldas (2009), a atividade da tradução (assim como o da educação) alinha-se muitas vezes a um discurso religioso, que faz circular sentidos de dedicação espiritual, fé e, sobretudo, obediência. Para a autora, a partir do discurso religioso, por exemplo, circulam preceitos de cultivo da fé, educação como sacerdócio, respeito à palavra de Deus etc. Assim, ainda que Lobato criticasse a Igreja, o uso de "abnegado" marca a presença do discurso religioso em seu dizer - com a visão do tradutor como sacerdote - num movimento do "bom-sujeito"; ou seja, há assimilação, em que o sujeito se sujeita ao e reproduz (no sentido de Pêcheux) um discurso que conscientemente pretendia subverter.

Segundo Indursky (2000), há fragmentação das formas-sujeito. Resumidamente, é como se na periferia de uma mesma FD houvesse posiçõessujeito dissidentes, não dominantes. Como sabemos, as FDs comportam o que deve ser dito, mas também o que não deve ser dito e, de tempos em tempos, o movimento dos sentidos altera a hierarquia das posições-sujeito - o que era dominante passa a ser periférico e vice-versa. Assim, a contradição já está presente na própria FD. Além disso, é preciso lembrar que o processo de interpelação não é homogêneo, até porque consideramos que a história particular do sujeito está na raiz do processo de tomada de posição. Logo, um mesmo sujeito empírico pode tomar posições-sujeito até mesmo conflitantes no decorrer da produção de um texto. 
Se há assimilação no que tange a uma FD religiosa, há resistência no que diz respeito à $F D$ da/sobre a tradução no Brasil, já que os tradutores são propostos no fio do discurso como "abnegados trabalhadores". Uma vez que a tarefa do tradutor não era reconhecida na época de Lobato, o uso do adjetivo sugere, pelo funcionamento do discurso religioso, que os tradutores fazem seu trabalho com altruísmo, desapego e renúncia. Ao chamá-los de "trabalhadores", o sujeito-Lobato se identifica com um discurso contrário à falta de reconhecimento reinante, propondo uma vez mais a atividade tradutória como árdua. Percebemos, então, um movimento do "mau-sujeito", daquele que se rebela contra o discurso dominante da FD da/sobre a tradução no Brasil.

No parágrafo seguinte, Lobato continua a sustentar essa posição de valorização do tradutor e, portanto, de resistência:

O homem de uma só língua, que entra na biblioteca e pode ler o Banquete de Platão [...] o Fausto e tanta coisa, admira os autores mas não tem uma palavra para a formiga humílima - o tradutor graças à qual aquelas obras lhe caíram ao alcance. Para o tradutor não haverá nunca remuneração econômica, nem glória, nem sequer a gratidão dos homens, só há insultos quando não faz o trabalho perfeito. Não obstante, a coisa suprema do mundo mental: universalização do pensamento - é obra deles (LOBATO 1959: 237, grifos nossos).

O projeto ideológico de Lobato se baseava nessa "universalização do pensamento". O escritor/editor/tradutor desejava nutrir o povo brasileiro com obras de diversas culturas, para que novos modos de pensar se fizessem presentes, o que seria conseguido também por meio de traduções feitas com qualidade. Daí a necessidade tanto de discutir a atividade quanto a de reconhecer o trabalho do tradutor - de tão renegado (só lhe restam “insultos”), é uma formiguinha mínima, porém capaz de uma atividade de tão grande monta e importância para o desenvolvimento e a renovação do país. Continuando o processo de contraidentificação/resistência, Lobato diz: 
MELLO, G. C. C. DE - Tradução, assimilação, resistência e discurso

A América Latina acaba de receber um alto presente elaborado por uma dessas tenazes abelhas da internacionalização, Benjamin de Garay, com seu transplante para o castelhano de Os Sertões de Euclides da Cunha. Graças a Garay, o formidável tríptico brasiliano - a Terra, o Homem e a Luta - tornou-se acessível ao mundo de língua espanhola (LOBATO 1959: 237, grifos nossos).

A pequenez do tradutor é novamente abordada de forma figurativa primeiro, "formiga", agora "abelha", talvez porque a abelha, ainda que pequena, como a formiguinha tradutora, seja capaz de atingir grandes distâncias. O uso de “internacionalização" também é relevante. 0 deslocamento dos intelectuais e de suas obras nas diversas culturas é antigo. Lobato em 1938 vislumbrava a relevância da integração dos povos para o fortalecimento das culturas e identidades nacionais e, segundo ele, os agentes mais importantes desse processo eram os tradutores que, consequentemente, deveriam ser mais valorizados. Não seria incorreto dizer que Lobato foi figura fundamental no processo de reconhecimento da atividade tradutória no Brasil.

Lobato termina o artigo novamente aludindo à relevância do trabalho de tradução:

Como não considerar imenso um livro que reproduz com fidelidade de espelho uma vida de significação imensa? E como não concluir que é imensa a paga dum tradutor quando transplanta para a sua língua uma obra assim? (LOBATO 1959: 245).

Em $A D$, entendemos que a pontuação também produz efeitos de sentido. No caso da SD acima, os pontos de interrogação funcionam não como um questionamento, mas como uma reafirmação do absurdo de não se dar a devida atenção aos tradutores e ao seu trabalho, ou seja, como reafirmação/materialização da resistência. Temos uma contraidentificação, um movimento contrário ao que era permitido pelo interdiscurso da FD da/sobre a tradução no Brasil, o qual sustentou a publicação de várias traduções sem que constasse sequer o nome do tradutor. Por outro lado, o 
tradicional discurso da fidelidade também se materializa, em um processo de identificação-assimilação.

\section{Considerações Finais}

A partir da relação entre língua e ideologia, procuramos entender como um sujeito-tradutor pode responder ao seu processo de sujeição à ideologia, seja na forma da repetição de discursos - o que denominamos assimilação ou na da subversão dos mesmos - o que denominamos resistência. Sustentamos que uma análise do funcionamento do discurso, tal como aqui proposta, permite que se chegue às marcas das filiações (des)conhecidas do sujeito-tradutor, as quais podem implicar, dentro da contradição e tensão que as sustentam, um caminho para entender como o sujeito pode atuar nas próprias instâncias que o assujeitam.

\section{Referências Bibliográficas}

AltHUSSER, L. Aparelhos ideológicos de estado. RJ: Graal, [1970] 1985.

CALDAS, B. F. Discursos sobre/de tradução no Brasil: línguas e sujeitos. Tese de Doutorado. Niterói: UFF, 2009, inédita.

COURTINE, J-J. Analyse du discourse politique. Langages, Paris, n. 62, 1981.

FURLAN, M. Brevíssima história da teoria da tradução no Ocidente. II Idade Média. In: Cadernos de Tradução 12. Florianópolis: Núcleo de Tradução, pp. 09- 28, 2003.

Foulcault, M. Arqueologia do saber. Rio de Janeiro: Forense Universitária, [1969] 2005. 
MELLO, G. C. C. DE - Tradução, assimilação, resistência e discurso

Frota, M. P. A singularidade na escrita tradutora: linguagem e subjetividade nos estudos da tradução, na linguística e na psicanálise. Campinas e SP: Pontes e FAPESP, 2000.

INDURSKY, F. A fragmentação do sujeito em análise do discurso. In: INDURSKY, F. e Campos, M. do C. (Orgs). Discurso, memória, identidade. Porto Alegre: Sagra Luzzato, 2000: 70-81.

- Formação discursiva: ela ainda merece que lutemos por ela? In: InDURSKY, F.; FERREIRA, C. L. (Orgs). Análise do discurso no Brasil: mapeando conceitos, confrontando limites. São Carlos: Claraluz, 2007: 163-172.

LACAN, J. A instância da letra no inconsciente. In: Escritos. 1998 [1966]: 496536.

LEITE, N. V. Só há causa daquilo que falha. In: Estudos da Lingua(gem). Vitória da Conquista, 2005: 77-82.

Loвato, M. Obras completas de Monteiro Lobato - Conferências, artigos e crônicas. V. 15. São Paulo: Brasiliense, 1959.

MAGalHÃES, B.; MARIANI, B. Processos de subjetivação e identificação: ideologia e inconsciente. Linguagem em (Dis)curso, v. 10, n. 2. Palhoça, SC, pp. 391408, 2010.

MARIANI, B. Subjetividade e imaginário linguístico. Linguagem em (Dis)curso, Tubarão, v. 3, número especial, pp. 55-72, 2003.

MelLo, G. C. C. de. Assimilação e resistência sob uma perspectiva discursiva: o caso de Monteiro Lobato. Tese de Doutorado. Rio de Janeiro: PUC-Rio, 2010, inédita.

ORLANDI, E. P. Análise do discurso: princípios e procedimentos. Campinas, SP: Pontes, 2005 [1999].

PÊCHEUX, M., FUCHS, C. Análise automática do discurso (AAD-69). In: GADET, F., HAK, T. Por uma análise automática do discurso, 3 ed. Campinas: Unicamp, 1997: 61-162.

PÊCHEUX, M. Semântica e discurso: uma crítica à afirmação do óbvio. Campinas: Unicamp, 1988[1975]. 2006[1983].

VenUtI, L. A invisibilidade do tradutor. Palavra. Rio de Janeiro: PUC-Rio, v. 3, pp.111-134, 1995[1986]. 
MELLO, G. C. C. DE - Tradução, assimilação, resistência e discurso

Escândalos da tradução. Baurú, São Paulo: EDUSC, 2002[1998]: 129167.

Recebido em: 15 set. 2015 Aprovado em: 14 dez. 2015

TradTerm, São Paulo, v. 26, Dezembro/2015, pp. 13-38

www.usp.br/tradterm

http://www.revistas.usp.br/tradterm/index 